University of the Pacific

Scholarly Commons

6-1-2011

\title{
Diasporic Designs of House, Home, and Haven in Toni Morrison's Paradise
}

Cynthia Dobbs

University of the Pacific, cdobbs@pacific.edu

Follow this and additional works at: https://scholarlycommons.pacific.edu/cop-facarticles

Part of the English Language and Literature Commons

\section{Recommended Citation}

Dobbs, C. (2011). Diasporic Designs of House, Home, and Haven in Toni Morrison's Paradise. Melus: Multi-ethnic Literature of The U.S., 36(2), 109-126. DOI: 10.1353/mel.2011.0020

https://scholarlycommons.pacific.edu/cop-facarticles/277 


\section{Diasporic Designs of House, Home, and Haven in Toni Morrison's Paradise \\ Cynthia Dobbs \\ University of the Pacific}

[T] he question of essentialism is no more than the question of interiority. Which is to say that identity theory is necessarily spatial theory.

—Mark Wigley (388)

Globalization, I want to suggest, must always begin at home.

—Homi K. Bhabha (xv)

What it is to live at the edge of towns that cannot bear your company.

—Toni Morrison (Nobel )

In April 1994, while working on the novel that was then titled War but would be published as Paradise, Toni Morrison addressed an audience at Princeton University's "Race Matters" conference with a talk titled simply and evocatively "Home." Later reprinted in the collection The House That Race Built (1998), "Home” focuses on Morrison's ongoing attempt to expose and alter the conventional relationship between language and race — a relationship that most of her literary and critical work addresses. In the Princeton lecture, describing what will become the novel Paradise and quoting from the novel Jazz, Morrison employs the metaphors of space and place to think through these intellectual and aesthetic preoccupations: "In my current project I want to see whether or not race-specific, race-free language is both possible and meaningful in narration. And I want to inhabit, walk around, a site clear of racist detritus; a place where race both matters and is rendered impotent; a place 'already made for me, both snug and wide open"” (9). Imagining a "safe space for race," Morrison quotes extensively from the manuscript that will become Paradise. Both in the essay and in the section of the novel that she read, Morrison moves the idea of home from one contained within the concept of "house" to an explicitly 
gendered, open-borders communal space - its freedom and security defined by the degree to which black women feel simultaneously safe, free, and connected:

I want to imagine not the threat of freedom, or its tentative panting fragility, but the concrete thrill of borderlessness - a kind of out of doors safety where "a sleepless woman could always rise from her bed, wrap a shawl around her shoulders and sit on the steps in the moonlight. And if she felt like it she could walk out the yard and on down the road. No lamp and no fear. A hiss-crackle from the side of the road would never scare her because what ever it was that made that sound, it wasn't something creeping up on her. Nothing for miles around thought she was prey. She could stroll as slowly as she liked, thinking of food preparations, of family things, or lift her eyes to the stars and think of war or nothing at all. Lampless and without fear she could make her way. And if a light shone from a window up a ways and the cry of a colicky baby caught her attention, she might step over to the house and call out softly to the woman inside trying to soothe the baby. The two of them might take turns massaging the infant stomach, rocking, or trying to get a little soda water down. When the baby quieted they could sit together for a spell, gossiping, chuckling low so as not to wake anybody else. The woman could decide to go back to her bed then, refreshed and ready to sleep, or she might stay her direction and walk further down the road—on out, beyond, because nothing around or beyond considered her prey." (“Home” 9-10)

An edenic home is not signaled here by a domestic (private, interior) place; rather, home is expanded to include the houses of other women and the interstices between those houses, a borderless space that encompasses both house and beyond. This same passage in Paradise abuts a description of the violation by the men of Ruby of what has become house and home as haven, the Convent. The men have come to contain what they perceive in the Convent as the "female 
malice" toward their communal home. In so doing, they repeat the very violent "disallowing" that generated the community's diasporic quest for home-as-haven in the first place (189).

Since the publication of Paradise, many critics have analyzed the dynamics of this tragic repetition-with-a-difference of communal rejection. Some have skillfully excavated how the ideas of diaspora, African American citizenship, gender, color, and race play out in the novel. ${ }^{1}$ Several critics note that Morrison couches these concerns in ideas of home, but few probe the ideas of home and house with much depth. My essay explicates Morrison's view of the relationships among house, home, and haven that are dramatized in Paradise and addresses these ideas' centrality to some of Morrison's nonfiction work. These relationships open up questions that cut to the core of African American identity: What does an American home mean to African Americans as a group whose origins in the United States stemmed from a profound unmooring from African homes? How are house and home related, particularly for a population historically dispossessed of both and of the fundamental American rights to property and happiness that house and home signify? How does the relationship between house and home shift under the pressure of gender? What does Africa mean as home? What does the idea of home mean to anyone displaced because of color, ethnicity, sexuality, gender, and/or domestic violence in its most capacious sense - that is, "domestic" as family, social, or national space?

\section{House as Unhomely Home}

Architectural historians, postcolonial theorists, gender theorists, and cultural critics—all have theorized about the social meanings of house and home. Feminist theorists in particular have noted how houses have historically served as both solace and prison. ${ }^{2}$ Postcolonial theorists such 
as Edward Said and Homi K. Bhabha have deepened our thinking about the meanings of home for the exiled. Bhabha's inquiry into home and the "unhomely" has special relevance here; he defines what a true sense of home means by its absence:

To be unhomed is not to be homeless, nor can the "unhomely" be easily accommodated in that familiar division of social life into private and public spheres. The unhomely moment creeps up on you stealthily as your own shadow and suddenly you find yourself with Henry James' Isabel Archer, in The Portrait of a Lady, taking the measure of your dwelling in a state of "incredulous terror.". . . The recesses of the domestic space become sites for history's most intricate invasions. In that displacement, the borders between home and world become confused; and, uncannily, the private and public become part of each other, forcing upon us a vision that is as divided as it is disorienting. (13)

Bhabha acknowledges that a physical house does not guarantee a sense of safety and belonging, with every domestic space remaining vulnerable to “history's invasions." Morrison's Paradise amplifies and extends Bhabha's perspective, giving the theme of an "unhomely" domestic space her own African Americanist, feminist, and womanist twist. ${ }^{3}$

Riffing on such American literary ancestors as Nathaniel Hawthorne, F. Scott Fitzgerald, and William Faulkner, Morrison uses the symbol of the embezzler's house in Paradise as a figure for the quintessentially American (white) masculinist social design of mastery, while also playing with her readers' expectations of the gendered work that takes place in and through the house. ${ }^{4}$ Morrison's depiction of the pre-sacred Convent reads very much like a return not just to Jay Gatsby's West Egg home, but also back to Sutpen's Hundred in Absalom, Absalom! Each literary house signifies its designer/owner's quintessentially American project: to remake the self as an inviolate, powerful (white) patriarch. The patriarchs in both The Great Gatsby and Absalom, 
Absalom! are felled by figures from their own repressed and oppressed pasts; Gatsby and Sutpen are brought down by the repudiated lower-class figures their houses' grandeur was meant to exclude. Race overlaps in profound ways with class in Absalom, Absalom! and more elliptically in The Great Gatsby, but class is the bedrock category in each case. Morrison thus reveals how utopian designs emblematized by the house are often based on a repudiation and disavowal of an underclass that includes the poor, the nonwhite, and women.

The imagined and literal space of home-as-haven for women is opened quite violently in this novel, with its explosive first line: "They shoot the white girl first" (3) — a dramatic entrée that establishes Morrison's serious play with readers' expectations about race matters. By the end of the novel, however, we find that, as Morrison put it in the "Home" essay, race "both matters and is rendered impotent" (4). Readers search for clues to identify "the white girl," only to find that it does not really matter. After establishing on the novel's first page the number, if not the names or race, of the hunted and hunters and defining what "home" would mean to the hunted, Morrison describes meticulously the domestic space of anticipated violence:

Then there is the grandeur. Only the two who are wearing ties seem to belong here and one by one each is reminded that before it was a Convent, this house was an embezzler's folly. A mansion where bisque and rose-tone marble floors segue into teak ones. Isinglass holds yesterday's light and patterns walls that were stripped and whitewashed fifty years ago. The ornate bathroom fixtures, which sickened the nuns, were replaced with good plain spigots, but the princely tubs and sinks, which could not be inexpensively removed, remain coolly corrupt. The embezzler's joy that could be demolished was, particularly in the dining room, which the nuns converted to a schoolroom, where stilled Arapaho girls once sat and learned to forget. 
Now armed men search rooms where macramé baskets float next to Flemish candelabra; where Christ and His mother glow in niches trimmed in grapevines. The Sisters of the Sacred Cross chipped away all the nymphs but the curves of their marble hair still strangle grape leaves and tease the fruit. The chill intensifies as the men spread deeper into the mansion, taking their time, looking, listening, alert to the female malice that hides here and the yeast-and-butter smell of rising dough. (3-4)

The house's opulent perversity, its patently adolescent male manifestations of an “embezzler's folly" - a sort of Playboy mansion out in the territory — are enough to give pause. The layered nature of the description is truly remarkable, with its swift segues from Jazz-Age masculine excess, to deep religious unease with female sexuality, to a religious view coupled with a colonialist disciplinary zeal (the erasure of memory and history at the core of the project), to a sense of "female malice" so threatening only murder can eliminate it.

Morrison returns to the house's "coolly corrupt" nature in a later passage again notable for its design detail. The light she throws on interior spaces illuminates the social and cultural designs operating in the novel's world. The house's architecture makes manifest its original owner's deepest fears and desires. The fear of the power of female sexuality remains common throughout many cultures and societies, and yet here it is directly linked to a Jazz-Age revolution of sexual mores amplified by Morrison's deft metonymic connection of sexuality and violence. Here, for instance, in the chapter titled "Grace," is Paradise's fullest description of the house's original design:

Fright, not triumph, spoke in every foot of the embezzler's mansion. Shaped like a live cartridge, it curved to a deadly point at the north end where, originally, the living and dining rooms lay. ... 
The four teaching sisters who moved into his house when it was offered for sale at a pittance diligently canceled the obvious echoes of his delight but could do nothing to hide his terror. The closed-off, protected "back," the poised and watchful "tip," an entrance door guarded by the remaining claws of some monstrous statuary, which the sisters had removed at once. A rickety, illhanging kitchen door the only vulnerability. (71, emphasis added)

As this quotation suggests, the Convent is a site to enact the nuns' Christian design to cleanse from the Arapaho girls' consciousness their indigenous religion and traumatic cultural memories along with any access to female sexuality. The building's resistance to complete erasure simultaneously asserts a counter-design: a return of repressed history, desire, and fear. ${ }^{6}$ The remaining architecture encodes the novel's various utopian designs to erase difference, resistance, and the sheer messiness of history, while also exposing the failure of such designs. This masculinist mansion of iniquity, turned Convent, then transformed into true haven for the utopian town's female castoffs and scapegoats, becomes a palimpsest of failed white and black patriarchal designs. What begins as a white male design for violent self-protection and objectified sexuality is temporarily transformed by the diverse women who inhabit the space into a haven from the excesses of black patriarchy.

Perhaps Pallas's encounter with this refurbished mansion/Convent/home best evinces Morrison's dream of the haven of a truly engendered house and home. In the following passage, Morrison's language in "Home" echoes through Paradise's description of an ideal space for a racialized yet race-free identity and language:

Pallas, bred in the overlight of Los Angeles, in houses without basements, associated them with movie evil or trash or crawly things. She gripped Seneca's hand and breathed through her mouth. But 
the gestures were expressions of anticipated, not genuine alarm. In fact, as they climbed the stairs, images of a grandmother rocking peacefully, of arms, a lap, a singing voice, soothed her. The whole house felt permeated with a blessed malelessness, like a protected domain, free of hunters but exciting too. As though she might meet herself here — an unbridled, authentic self, but which she thought of as a "cool" self—in one of this house's many rooms. (177)

Morrison's language evokes a psychoanalytic reading, with the cellar figuring as the unconscious - denied in the "overlight of Los Angeles"- and present for negotiation out here in the territory. But Morrison also taps into a long womanist tradition, calling up a multigenerational maternal presence in a grandmother's lap and voice. This space is associated with sound (rather than language/the Law of the Father) and the maternal body becomes a creative space for that illusory holy grail for the twentieth-century unhomed exile: a home in which one might find authenticity of self. It is crucial that under the influence of the Convent women, the house becomes not simply a home, but, through the metonymy of memory, a spiritualized body, a corporeal spiritual ground. Morrison dramatizes what Dolores Hayden theorizes: "The house is an image of the body, of the household, and of the household's relation to society; it is a physical space designed to mediate between nature and culture, between the landscape and the larger urban built environment" (40). In Paradise's Convent, Morrison uses the house to signify a radical transformation of this mediation through its last inhabitants.

The chief architect of the final transformation of the Convent from house to home is Consolata, one of Morrison's characteristic wise women and what Andrea O'Reilly dubs a "community mother" (5). Like Baby Suggs in Beloved, Consolata sees the body as the space for a self-claiming - a site for decolonization, regendering, and regeneration. The racialized and gendered body is historically a contested location for battles of domination and control. This 
most intimate and individual territory, Consolata insists, must be reclaimed first. ${ }^{7}$ Aptly enough it is in the house's cellar, a space of the unconscious, a space not yet designed as someone else's fantasy, that Consolata prepares the women for their own spiritual liberation.

In the beginning the most important thing was the template. First they had to scrub the cellar floor until its stones were as clean as rocks on a shore. Then they ringed the place with candles. Consolota told each to undress and lie down. In flattering light under Consolata's soft vision they did as they were told. How should they lie? However you feel. . . . When each found the position she could tolerate on the cold, uncompromising floor, Consolata walked around her and painted the body's silhouette. (263)

From the architectural blueprints of the embezzler's masculinist mansion, we have moved to Consolata's spiritual yet emphatically corporeal template, a space for self-design and selfauthorship. Like many of Morrison's heroines, Consolata insists on a profoundly embodied spirituality. As she puts it, "My bones on hers the only good thing. Not spirit. Bones. No different from the man. My bones on his the only true thing. So I wondering where is the spirit lost in this? It is true, like bones. It is good, like bones. One sweet, one bitter. Where is it lost? Hear me, listen. Never break them in two. Never put one over the other" (263). It is Consolata's fiercely physical love of Deacon, whose lip she bites hard enough to draw blood, that drives him to retreat, generating her initial descent into despair. Importantly, she defends this love-hungry action as an expressed desire to return through sexual love to a home: "Dear Lord, I didn't want to eat him. I just wanted to go home" (240).

The women who occupy the Convent as house and fragile home have all previously escaped from what Bhabha would dub "unhomely" spaces. They have seen that the abode that promises 
full inclusion in America - the suburban home - reveals itself as vulnerable and even dangerous. Mavis's and Pallas's homes offer clear domestic dangers, and even Dovey Morgan's perfect ranch house unsettles her. As the wife of one of Ruby's most powerful citizens, one of the wealthy "blue black, 8-rock" insiders with houses in the city and country, Dovey would seem to have achieved the American dream (193). Morrison reveals the dream as illusory, however, by having Dovey be drawn to another house entirely as her space of belonging. A house in foreclosure, a no-man's land of non-ownership, serves as Dovey's haven. If Paradise explodes the idea of (African) American home ownership as key to a sense of belonging, the novel's depictions of what I call "external domestic" spaces provide a view of what an African American home-as-haven might look like.

\section{Home Unhoused}

In classic Western traditions, the kitchen figures as the most feminine of already feminized domestic spaces. Yet the Oven in Paradise is moved outside the domestic, private sphere, capitalized, and rendered a public monument to the community's will to survive. The embezzler's phallic house is transformed into a feminized, matriarchal space where male desire is not erased but kept at bay. Meanwhile, in Haven and then in Ruby, Morrison turns the conventionally feminine domestic space of the kitchen inside out, rendering the Oven a public icon of the town fathers' utopian plans. Private, feminine utility becomes public, masculine memorial. When the Old Fathers' design for Haven begins to falter, the next generation of men establish a new black utopia, Ruby. And, despite the doubts of the community women, they take only one architectural artifact with them to this new town- the Oven: 
As new fathers, who had fought the world, they could not (would not) be less than Old Fathers who had outfoxed it; who had not let danger or natural evil keep them from cutting Haven out of mud and who knew enough to seal their triumph with that priority. An Oven. Round as a head, deep as desire. ... [T]he Old Fathers did that first; put most of their strength into constructing the huge, flawlessly designed Oven that both nourished them and monumentalized what they had done. (6-7)

Note that this "flawless" design attempts a paradox: to "nourish" and "monumentalize" simultaneously. It is emblematic of the failure in the Founding Fathers' fantasy of a "flawlessly designed" social paradise: the illusion that a monument to the past can, without change, carry a diverse, changing community into the future.

If the Oven's transformation into masculinist memorial seems to disrupt notions of the feminized nature of domestic space, Morrison's careful historicizing impulse complicates this interpretation. For the legacy of slavery transforms such a gendered (white) dichotomy of private/kitchen/feminine vs. public/open/masculine: the Oven carries significance for the Old Fathers precisely because it signals their female ancestors' liberation from the plight of their "house slave" sisters. To be placed in the kitchen of the master in slavery was to be made perpetually sexually vulnerable, whereas to be a "lower" field slave was to have the ironic protection of public space. ${ }^{8}$

Given Morrison's suspicion of the monumental, it is no surprise that her female characters view the Oven from quite a different angle: 
Minus the baptisms the Oven had no real value... The women nodded when the men took the Oven apart, packed, moved and reassembled it. But privately they resented the truck space given over to it — rather than a few more sacks of seed, rather than shoats or even a child's crib. ...

A utility became a shrine (cautioned against not only in scary Deuteronomy but in lovely Corinthians II as well) and, like anything that offended Him, destroyed its own self. (103-04)

By the novel's end, when the murdered Convent women have been resurrected, this Oven has failed to nourish anything but violence. It has begun to falter even as a monument to the town's patriarchs and its mythic history. As the town's men divide over the wording and proper interpretation of the Oven's inscribed message ("Beware" or "Be" the "Furrow of His Brow" [195]), the Oven's foundations literally begin to shift and sink. It collapses under its own reified weight—not despite but because of its "flawless design."

We can relate the failure of the Oven's "flawless" masculinist design to the idea of "the changing same," a tradition that is sustained only through retention and transformation. The "changing same" has become a commonplace in African American cultural theory and criticism. ${ }^{9}$ Deborah McDowell's critique of the charges against black women writers in the 1970s and 1980s resonates uncannily with Morrison's Paradise. McDowell's analysis of the forces generating the critical attack on these writers as "anti-male" applies readily to the forces inspiring the male characters in Paradise to turn so viciously on the Convent's women. McDowell writes:

$[T]$ hese attacks ... relied on an enfeebled black nationalism, long past saving, which, like other nationalist rhetorics, was bound up in masculinist anxieties and gendered ideologies of dominance and control. Metaphors of "family," "kinship," and "community" structured these attacks that 
bordered on calls for censorship and attempted to demand that black women writers meet a representational ideal in the name of creating racial unity and wholeness. (xv-xvi)

The black nationalism of the younger generation in Paradise might very well be "long past saving" even at its highpoint in the early 1970s setting of the novel. The movement was doomed, however, not for the reasons the older generation in the novel offers: a lack of respect for tradition, a baffling (to some) embrace of African cultural roots, an unabated assertiveness. Rather, the movement's demise was precisely due to the its "masculinist anxieties and gendered ideologies of dominance and control." ${ }^{\prime 10}$

For a more benevolent homelike place, Morrison ultimately chooses a space that initally seems unlikely to serve as true home for Ruby's citizens: Anna Flood's store. Transformed by the mixed color Anna Flood, one of the novel's insider-outsiders, the store becomes a site for a more capacious notion of home, one that serves as haven for a fluid community—and in which the global forces of change are neither feared nor escaped but instead negotiated and welcomed. Anna's mixed racial background marks her as one of Bhabha's "unhomed," uncomfortably yet redemptively outside the Original Family of Ruby. Her liberation from the stagnant tradition of the 8-rock ideology shows in her approach to design. With the Oven, Morrison troubles our notions of private and public space, the feminine domestic and masculine public. With Anna Flood's store, she takes this deconstruction of construction a step further, blurring the mercantile and the maternal, the commercial and the spiritual, and the retail and the religious.

To understand the significance of Anna Flood's design, however, we must return to the original space, her Founding Father's space: 
Ace Flood's faith had been the mountain-moving kind, so he built his store to last. Sturdier than some churches. Four rooms for his family above; below, a spacious storeroom, a tiny bedroom, and a fifteen-foot-high selling area crammed with shelves, bins, cases and drawers. The windows were regular house type — he didn't want or need display; no big, wasteful "looking-in" plate glass for him. Let folks come inside to see what he had. He didn't have many things but he had a lot of what he stocked. (120)

Morrison gives Ace Flood's entrepreneurship a distinctly religious flavor. From the "mountainmoving" faith of his ambitious construction ("sturdier than some churches"), to the Puritan resistance to "wasteful" display, to the loaves-and-fishes abundant simplicity of his stock, Ace Flood's store palpably evinces Ruby's Protestant values.

What becomes of Ace Flood's store also tells a story of the fate of those values amid the larger national and global, economic and social transformations that intrude on Ruby's desire for a self-sustaining, black-owned economy: "Before he died, he saw his store change from a necessary service in Ruby to a business patronized by the loyal for certain items, though they balked at his prices and more and more drove their trucks to Demby for cheaper (and better) supplies" (120). Ace's inability to respond to those changes threatens the viability of this space. The blueprint for a design "built to last" becomes a straight-jacket. Ace's daughter Anna, however, transforms the store into a space that works for the "changing same" of the community:

Anna changed all that. What Ace's Grocery now lacked in size of inventory it gained in variety and style. She offered free coffee on cold days, iced tea when it was hot. She put out two chairs and a small table for the elderly and those who drove in from farms and wanted to rest awhile. And since adults, nowadays, never frequented the Oven next to her store- except for special events - she 
catered to the appetites of the young who liked to gather there. She sold her own pies, made her own candy along with the lots she picked up in Demby. She kept three kinds of soda pop instead of one. Sometimes she sold the black-as-eight-rock peppers the Convent grew. She kept hog's head cheese in the cooler, as her father had, along with local butter and salted pork. But canned goods, dried beans, coffee, sugar, syrup, baking soda, flour, catsup, paper products - all the items nobody could or wanted to make at home - took up the space Ace Flood once used for cloth, work shoes, light tools, kerosene. (120)

In a tacit agreement about a mutually beneficial division of goods and services, Anna Flood works with the other local businesses (Sergeant's Feed and Seed and Harper's drugstore) to ensure that her customers' mercantile needs are met. Her updated inventory reflects twentiethcentury post-war shifts in production, distribution, and consumption, but it also displays a respect for local cultural history and values: the mass-produced cozies with the locally grown and made. Most important, Anna's inventory caters to the next generation of the town, while her design ensures a space not merely for shopping, but for communing. The table and chairs she puts out for the elderly and rural visitors guarantee that all community members' mercantile and social needs are met. Anna's ability to update the store's design to meet the changing same of her community also pays off in profits. Morrison attributes the store's success under Anna's leadership to its "variety, comfort and flexibility" (120). What is crucial here is that Anna's economic profits derive from her sensitivity to her community's changing desires and requirements and her ability to reshape the original Old Father's designs for the store to meet the heterogeneous needs of her town.

\section{Africa as Home? The Global and the Local}


What Morrison describes as a figurative house and home in her 1994 address becomes, in Paradise, a house and home both figurative and material, its design exposed as fretfully (and futilely) determined to control women. I conclude my reading of Paradise with a brief look at how Morrison's domestic designs in her novels are also deeply affected by her characters' interaction with global concerns. Morrison's interest in this clash is deep and ongoing. From Sula through Paradise, to Morrison's 2006 curatorship of a multidisclipinary exhibit at the Louvre, which she titled "The Foreigner's Home," we can trace her developing sense of the connection between a fierce longing for a local, regional, and national home - in short, an African American situated identity—and a transnational, postcolonial notion of diasporic exile. "The Foreigner's Home" springs from the idea of home as a way of addressing, in Morrison's words, "the pain and rewards of displacement, immigration and exile" (qtd. in Riding). In her address at the exhibit's opening, Morrison argued that to explore the idea of the foreigner's home is to "require us to come to terms with being, fearing or accepting the stranger" (qtd. in Riding). Granted, the Louvre exhibit deals with exile on a global scale, whereas Paradise focuses intently on the internal exile of African Americans in Oklahoma-yet the language Morrison uses in "The Foreigner's Home" to depict diasporic longing and fear illuminates Paradise's narrative of sequential traumatic displacements, fear-driven disavowals, and longings for acceptance. In fact, one of Morrison's powerful subtending points in her writing is that global diaspora is also always inevitably a domestic issue, as diaspora is experienced in deeply individual, regionally rooted ways.

From the opening pages of Paradise, Morrison establishes connections between international concerns (in particular, international warfare) and domestic violence defined most inclusively, not only as the terrifyingly intimate violence in the home, but also as the often violent struggle of 
African Americans for full citizenship. From the early mention of Mavis's brothers killed in Vietnam (linked opaquely to the suffocation death of her two babies), to Deek and Soane Morgan's slain sons, to the genetic vulnerabilities of Jeff Fleetwood's children after his tour in Vietnam, the war in Southeast Asia infuses this novel set so deeply within the Oklahoma territory. It is no small point that Paradise's original title was "War." To understand the role of home in Paradise is to understand the social fears and desires driving violence on any scale. Morrison reveals the singular desire shared by all those fighting for paradise in its distinct, often violently opposing forms: a liberatory home, a space in which both belonging and freedom are possible.

Paradise's most intellectual characters, Richard Misner and the town historian, Patricia [Pat] Best, get to the heart of the diasporic longing for home in a remarkable conversation mid-novel. Ruby's Christmas pageant, a Christian master narrative revised to tell the story of the town's birth, takes place literally on stage but also off-stage from Richard and Pat's debate about the role of Africa in the community's longing for home. In what must be Morrison's most startlingly direct commentary on African American historiography, Pat and Richard wrestle with the place of slavery and of Africa in their community's history. While Pat claims that "slavery is our past. Nothing can change that, certainly not Africa," Richard argues that "Africa is our home, Pat, whether you like it or not" (210). Pat seems to win this argument with Richard, exposing a certain naiveté or wishful thinking behind Richard's black nationalist embrace of an African homeland:

I just don't believe in some stupid devotion to a foreign country — and Africa is a foreign country, in fact it's fifty foreign countries - is a solution for these kids. ... You want some foreign Negroes to identify with, why not South America? Or Germany, for that matter. They have some brown babies 
over there you could have a good time connecting with. Or is it just some kind of past with no slavery in it you're looking for? (210)

If Pat cuts through Richard's sentimental notion of an African home, uncovering its historical and geographical fuzziness, she also has no real response to the emotional power of his homiletic depiction of Africa as a true home, of what it might mean to the "unhomely." To Pat's defense of Ruby_ "This is their home; mine too. Home is not a little thing"-Richard responds with historical acuity, global reach, and spiritual longing:

I'm not saying it is. But can't you even imagine what it must feel like to have a true home? I don't mean heaven. I mean a real earthly home. Not some fortress you bought and built up and have to keep everybody locked in or out. A real home. Not some place you went to and invaded and slaughtered people to get. Not some place you claimed, snatched because you got the guns. Not some place you stole from the people living there, but your own home, where if you go back past your great-greatgrandparents, past theirs, and theirs, past the whole of Western history, past the beginning of organized knowledge, past pyramids and poison bows, on back to when rain was new, before plants forgot they could sing and birds thought they were fish, back when God said Good! Good!- - there, right there where you know your own people were born and lived and died. Imagine that, Pat. That place. Who was God talking to if not to my people living in my home? (213)

The earthly home here in Richard's eloquently evoked transnational, post- and pre-colonial vision is Africa. But for the characters in Morrison's Paradise and for its readers, the struggle is to build a contemporary home, one that acknowledges historical complexity and transcontinental cultural rupture and retention. Morrison's characters yearn for Africa as home, but they also never give up on the dream of an American home as haven. 
Morrison's nuanced vision of the local and global meanings of home draws heavily from the postcolonial theories of Bhabha and Said. Bhabha links the national and the global through the term "home" explicitly:

Globalization, I want to suggest, must always begin at home. A just measure of global progress requires that we first evaluate how globalizing nations deal with "the difference within"- the problems of diversity and redistribution at the local level, and the rights and representations of minorities in the regional domain. In the United States, for instance, the American dream is sustained by the "wave theory" of migration — the Irish, followed by the Italians, Jews, Koreans and South Asians. There is, however, an ingrained insouciance, a structural injustice, shown towards African Americans or First Nations Peoples whose ethical and political demands for equality and fairness are based on issues of reparations and land-rights. These rights go beyond "welfare" or "opportunity" and make claims to recognition and redistribution in the process of questioning the very sovereignty of national traditions and territories. (xv)

Bhabha's insistence on the attention to local and national differences within postcolonial theories of the global is crucial. As he notes, global diaspora and the plight of national minorities are connected but not collapsible. ${ }^{11}$ Like Morrison's Pat Best, Bhabha refuses to submerge the "difference within" in the service of embracing an easy, stable pan-African identity. To collapse the local struggle of African Americans and the international struggles of Africans is not only to flatten historical and geographical complexities, but also to replicate an erasure of difference that drives diaspora in the first place. ${ }^{12}$ Said makes a similar point to the one Bhabha theorizes and Morrison dramatizes in noting the common, ironic repetition of exclusion and erasure of difference within the very political movements meant to respond to these injustices: 
The historical experience of imperialism for the imperialized entailed subservience and exclusion; therefore the historical experience of nationalist resistance and decolonization was designed for liberation and inclusion. Much of what went wrong in the subsequent development of nationalism was the direct result of either forgetting or rejecting this edifying equation. (xxvii)

"Liberation and inclusion." If anything, the failures and triumphs of community in Paradise evince precisely the forgetting of this marriage and the tragic repetition of the exclusionary impulse. Liberation remains, if not impossible, then at least unsustainable without inclusion.

Unlike Said and Bhabha, however, Morrison insists that women, in particular, must be central to any vision of communal liberatory identity. Each of these formidable thinkersMorrison, Said, and Bhabha — urges that even the most flawless designs for national and international social justice movements are doomed without an acknowledgment of the imperative of inclusion, in all its complexity and difficulty. No matter the scope and proximity of the very real external terrors (battlefronts from Normandy to Vietnam) in this novel, the violent differences within national boundaries are overlooked at everyone's peril. Morrison pushes us closer to the uncomfortable truth: if we are to acknowledge fearful difference, we must brave bringing the lens in ever tighter. In the words of Consolata, "Scary things not always outside. Most scary things is inside" (34).

\section{Notes}


${ }^{1}$ Of particular note are studies by Katrine Dalsgård, Linda Krumholz, and Rebecca Hope Ferguson.

${ }^{2}$ These scholars expose radically opposed notions about the precise gendered nature of "the house." On the one hand, Arthur C. Danto notes the long-standing association of the house and patriarchal power: "the house speaks to us precisely as the symbol of rulership, ownership, mastery, power" (9). On the other, Dolores Hayden, Mark Wigley, and Leslie Kanes Weisman argue for the house as site of the simultaneous feminization of space and the spatialization of femininity. Wigley offers a nuanced analysis of the web of social and cultural forces that shape the meaning of the interior of houses, a "kind of convoluted exchange between spatial and ideological transformations" (350). Weisman argues for the emphatically feminine nature of the house: "While vertical structures have, throughout history, served as sacred 'masculine' icons, the house has been inextricably associated with women, especially women's bodies." Weisman continues, noting that "in many modern works of art by women, images of the house, woman's body, and the role of house/wife merge symbiotically in a vivid social commentary on the house as woman's prison" (17). Wigley's discussion of Tuscan architect Alberti's fifteenth century work, On the Art of Building in Ten Books, offers tools for thinking about gender, race, and space in Paradise. Wigley notes that Alberti's architectural instructions enlist an array of highly gendered social proscriptions for the house's inhabitants, so that "the house is literally understood as a mechanism for the domestication of (delicately minded and pathologically embodied) women" (322). As Hayden states, "The house is an image of the body, of the household, and of the household's relation to society; it is a physical space designed to mediate between nature and culture, between the landscape and the larger urban built environment" (40). 
All of these gender theorists and architectural historians argue for the house as a space in which femininity is constructed — and as a space quite intentionally "feminized" in turn.

${ }^{3}$ Alice Walker revised the notion of black feminism to include a spiritual component. She gives her own "dictionary definition" of womanist:

Womanist.1. From womanish. (Opp. Of “girlish,” i.e., frivolous, irresponsible, not serious.) A black feminist or feminist of color. . . .

2. Also: A woman who loves other women, sexually and/or nonsexually. Appreciates and prefers women's culture, women's emotional flexibility....

3. Loves music. Loves dance. Loves the moon. Loves the Spirit. Loves love and food and roundness. Loves struggle. Loves the Folk. Loves herself. Regardless.

4. Womanist is to feminist as purple to lavender. (xi-xii)

The third definition of "womanist" seems particularly useful in a consideration of the transformation of the Convent residents, but all aspects of the definition fit.

${ }^{4}$ See Patricia Storace for a discussion of how Paradise echoes Hawthorne's The Blithedale Romance.

${ }^{5}$ See Kelly Lynch Reames for analysis of Morrison's play with readerly expectations regarding race in her renderings of vexed interracial friendships.

${ }^{6}$ This counter-design functions much in the same ways as Michel Foucault's and Hortense J. Spillers's notions of "counter-memory," a force disrupting the smooth surface of a hegemonic text.

${ }^{7}$ For a discussion of the hybrid spirituality Consolata practices, which draws deeply from Brazilian Candomblé, see J. Brooks Bouson (208-11, 238-40). 
${ }^{8}$ The subversion of public space to allow for protection echoes Harriet Jacobs's inversion of private space to employ public power in Incidents of the Life of a Slave Girl.

${ }^{9}$ See especially LeRoi Jones [Amiri Baraka] and Deborah McDowell.

${ }^{10}$ For an account of the sexism endemic to the black nationalist movement, see Elaine Brown.

${ }^{11}$ Carol Geary Schneider recently emphasized this same point, arguing that relatively recent academic institutional attention to the global must intersect with but not subsume the decadesrich work on US diversity within the academy.

${ }^{12}$ Bhabha continues, "A right to difference-in-equality can be articulated from the perspective of both national minorities and global migrants; and in each case such a right represents a desire to revise the customary components of citizenship-political, legal and social citizenship (T. H. Marshall)—by extending them to include the realm of 'symbolic citizenship' (Avishai Margalit). The symbolic aspect raises affective and ethical issues connected with cultural differences and social discrimination-the problems of inclusion and exclusion, dignity and humiliation, respect and repudiation" (xvii).

\section{Works Cited}

Bhabha, Homi K. The Location of Culture. 1994. New York: Routledge, 2004.

Bouson, J. Brooks. Quiet As It's Kept: Shame, Trauma, and Race in the Novels of Toni Morrison. Albany: State U of New York P, 2000.

Brown, Elaine. A Taste of Power: A Black Woman's Story. New York: Pantheon, 1992. 
Dalsgärd, Katrine. “The One All-Black Town Worth the Pain”: (African) American Exceptionalism, Historical Narration, and the Critique of Nationhood in Toni Morrison's Paradise." African American Review 35.2 (2001): 233-48.

Danto, Arthur C. “Abide/Abode.” Housing: Symbol, Structure, Site. Ed. Lisa Taylor. New York: Cooper-Hewitt Museum, 1990: 8-9.

Faulkner, William. Absalom, Absalom! (The Corrected Text). 1936. New York: Modern Library, 1993.

Ferguson, Rebecca Hope. Rewriting Black Identities: Transition and Exchange in the Novels of Toni Morrison. Brussels: Lang, 2007.

Fitzgerald, F. Scott. The Great Gatsby. 1925. New York: Scribner, 1999.

Foucault, Michel. Language, Counter-Memory, Practice: Selected Essays and Interviews by Michel Foucault. Ed. Donald F. Bouchard. Trans. Bouchard and Sherry Simon. Ithaca: Cornell UP, 1977.

Hayden, Dolores. Redesigning the American Dream: The Future of Housing, Work, and Family Life. New York: Norton, 1984.

Jacobs, Harriet. Incidents in the Life of a Slave Girl, Written by Herself. 1861. Ed. Jean Fagan Yellin. Cambridge: Harvard UP, 1987.

Jones, LeRoi [Amiri Baraka]. "The Changing Same (R\&B and New Black Music).” The Black Aesthetic. Ed. Addison Gayle, Jr. New York: Anchor-Doubleday, 1971. 112-25.

Krumholz, Linda. "Reading and Insight in Toni Morrison's Paradise." African American Review 36.1 (2002): 21-34. 
McDowell, Deborah. The Changing Same: Black Women's Literature, Criticism, and Theory. Bloomington: Indiana UP, 1995.

Morrison, Toni. “Home.” The House That Race Built: Original Essays by Toni Morrison, Angela Y. Davis, Cornel West, and Others on Black Americans and Politics in American Today. Ed. Wahneema Lubiano. New York: Vintage, 1998: 3-12.

—. The Nobel Prize in Literature Lecture. 1993. New York: Knopf, 1994.

—. Paradise. New York: Plume, 1999.

O'Reilly, Andrea. Toni Morrison and Motherhood: A Politics of the Heart. Albany: State U of New York P, 2004.

Reames, Kelly Lynch. “A Girl from a Whole Other Race': Toni Morrison’s 'Recitatif,” Paradise, and Beloved." Women and Race in Contemporary U.S. Writing. New York: Palgrave, 2007. 131-56.

Riding, Alan. "Entr'acte: At Louvre, Toni Morrison Hosts a Conversation on Exile." New York Times. 15 Oct. 2006. Web. 10 Sept. 2010.

<http://www.nytimes.com/2006/11/15/world/europe/15iht-entracte.3550088.html>.

Said, Edward. Reflections on Exile and Other Essays. Cambridge: Harvard UP, 2002.

Schneider, Carol Geary. "Civic Learning in a Diverse Democracy: Education for Shared Futures." Diversity and Democracy 10.3 (2007): 1-3.

Spillers, Hortense. "Mama’s Baby, Papa’s Maybe: An American Grammar Book.” Culture and Countermemory: The “American” Connection. Spec. issue of Diacritics 17.2 (1987): 64-81. Storace, Patricia. "The Scripture of Utopia.” The New York Review of Books. 11 June 1998: 6469. 
Walker, Alice. In Search of Our Mothers' Gardens: Womanist Prose. New York: Harcourt, 1983.

Weisman, Leslie Kanes. Discrimination by Design: A Feminist Critique of the Man-Made Environment. Urbana: U of Illinois P, 1994.

Wigley, Mark. "Untitled: The Housing of Gender." Sexuality and Space. Ed. Beatriz Colomina. Princeton: Princeton UP, 1992: 327-89. 